\title{
COMMENT
}

\section{EQUIPMENT LEASING BY MOTOR CARRIERS: RATE REGULATION AND JUDICIAL REVIEW}

Motor common carriers may be divided into two categories: those whose hauling equipment is owned by the carrier (self-sustaining carriers) and those whose hauling equipment, or part of it, is leased to the carrier (leasing carriers). In many cases leased equipment is operated by its owner (owner-operator), who is compensated by the lessee carrier on a mileage or revenue percentage basis.

The Interstate Commerce Commission uses various tests ${ }^{1}$ for determining whether a carrier's proposed rate is just and reasonable according to the Interstate Commerce Act. ${ }^{2}$ One of these tests is the determination whether a proposed rate is compensatory, i.e., whether the rate will produce revenue adequate to meet costs plus a fair return. ${ }^{3}$ Since carriers subject to the act must keep accounts in the manner prescribed by the Commission, ${ }^{4}$ self-sustaining carriers have in their records all the costs of movement; leasing carriers, however, do not have in their records all the costs of movement ${ }^{5}$ since most of the actual costs of movement are incurred by their owner-operators. Hence, in one rate proceeding in which the Commission's determination was to be made on the basis of the proposed rate's relationship to the costs of its generation, ${ }^{6}$ it became necessary for the Commission to decide whether the costs to be considered would be solely those incurred by the carrier-its expenses-or those incurred by the movement-the carrier's expenses plus the owner-operator's expenses. If the Commission were to choose the latter alternative, it would have to face the result that, unless the leasing carriers could produce the actual costs or offer indirect proof of the costs incurred by their owner-operators,"

1 See, e.g., Aluminum or Aluminum Articles from Newport, Ark., to the East, 306 I.C.C. 607 (1959); Aluminum or Aluminum Articles from or to Newport, Ark., 306 I.C.C. 579 (1959); Wire and Tubes from New Jersey to Memphis, Tenn., 305 I.C.C. 580 (1959); Cotton Piece Goods in the South, 304 I.C.C. 667 (1958).

$2 \S 216$ (b), 49 Stat. 558 (1935) ; 49 U.S.C. $\$ 316$ (b) (1964). (1945).

3 See, e.g., New Automobiles in Interstate Commerce, 259 I.C.C. 475, 499-530

4 Interstate Commerce Act $\S 204$ (a) (1), 49 Stat. 546 (1935), 49 U.S.C. $\$ 304$ (a) (1) (1964).

5 Iron or Steel Scrap from Connecticut, Massachusetts, and Rhode Island to Pennsylvania, 318 I.C.C. 567, 574 (1962).

"Motor carrier rate determinations are considered in terms of "operating ratios." The operating ratio is the ratio of the carrier's expenses of operation to its gross revenues. In general an operating ratio of .9 is considered adequate Obviously, since the motor carrier's investment is small compared to its costs of operation, the "fair return on full value" principle of rate setting is inapposite.

7 The burden of proof is on the carrier to show that the proposed rate change is just and reasonable. $\$ 216(\mathrm{~g}), 49$ Stat. $558(1935)$, as amended, 49 U.S.C. $\$ 316(\mathrm{~g})$ (1964). 
they would be foreclosed from the rate flexibility enjoyed by self-sustaining carriers. If the Commission were to choose the former alternative, it would have to face the possibility that leasing carriers, under the pressure of competition, might seek and obtain rates too low to attract the services of owner-operators, thereby unstabilizing their own operations.

\section{The Commission's Decision}

On the basis of a previous dictum, ${ }^{8}$ the Commission held in Floor Coverings or Related Articles from East to South ${ }^{9}$ that leasing carriers must, in order to have a rate reduction approved, prove that the proposed rate would exceed the costs of the movement by producing evidence of those costs. On appeal in Malone Freight Lines, Inc. v. United States, ${ }^{10}$ the Commission's position was sustained:

Whether rates are just and reasonable within the nebulous statutory standard is a question of fact to be resolved by the Commission after according appropriate weight to the evidence offered in their support. . . . It seems obvious that rates which are not compensatory are not just and reasonable. . . . No costs were presented whereby the Commission could determine whether the proportion of the gross revenue received by owner-operators is sufficient to represent a compensatory return, despite a previous admonition that the Commission was vitally interested in cost data for representative owner-operator movements.

The Commission found inadequate to support a finding that the proposed rates would be compensatory evidence relating to . . . [the carrier's] system average expenses. . . As we observed once before, "under the limited review here permitted, it cannot be held that the Commission erred in finding that the plaintiff had not met its burden of proof." 11

Eight months after the Malone Freight Lines decision, the Commission abandoned the Floor Coverings rule in Iron or Steel Scrap from Connecticut, Massachusetts, and Rhode Island to Pennsylvania. ${ }^{12}$ The leasing carrier had had its proposed rate in effect for over seven years; it compensated the owner-operators by paying them seventy percent of the gross revenues. ${ }^{13}$ The Commission's analysis was straightforward: the production of the actual costs it had hoped to achieve under the rule of Malone Freight Lines had not materialized. ${ }^{14}$ The Commission reasoned

8 Class Rates and Ratings, Malone Freight Lines, Inc., 304 I.C.C. 395, 398 (1958).

9 Class Rates and Ratings, Malone Freight Lines, Inc., 313 I.C.C. 530 (1961).

10204 F. Supp. 745 (N.D. Ala. 1962).

11 Id. at 754-55.

12318 I.C.C. 567 (1962).

$13 \mathrm{Id}$. at 572,575 .

$14 I d$. at 574 . 
that such production would require that owner-operators keep accounts in the manner prescribed for carriers, but

owner-operators are not subject to direct regulation by the Commission. They are not required to maintain accounts and records in any particular form. They are not required to file annual reports. Even if they were willing to supply cost data to the carriers they serve, the Commission would be unable to verify such information. ${ }^{15}$

Since

Under the present state of the law and Commission regulations, it is impossible to determine whether the division of the revenue retained by an owner-operator is sufficient to cover his costs. $^{16}$

Therefore

When . . . a division of the revenue fully compensates the carrier for providing the transportation service in question, the rate which produces that revenue must be regarded as reasonably compensatory. This does not mean, however, that any particular revenue split will result in automatic approval of the challenged rate. The Commission must be satisfied that the rate and the division thereof are sufficient to purchase the transportation service in question; that it is sufficient, in other words, to acquire or to retain the services of the owner-operators in the movement of traffic to which the rate is applicable. ${ }^{17}$

The Commission had weighed two considerations in reaching its decision : the leasing carriers' burden of producing actual costs evidence derived from the inadequate records of the owner-operators, and the need for rates which are compensatory not only to the costs of the carriers, but also to the costs of the movement. Hence an evaluation of the Commission's decision requires analysis of the weights of these two considerations. Since each of them is given full exposition in Commissioner Freas' dissent to the Iron or Steel Scrap decision, ${ }^{18}$ it is to that source we turn for the raw material of the analysis.

The Freas dissent deals first with the majority's conclusion that the actual costs incurred by the owner-operators are not and cannot be made available. It contends :

It is true that . . . an owner-operator . . . may not be directly subject to our jurisdiction. However, there is no question

15 Ibid.

18 Ibid.

17 Id. at 575 . (Emphasis added.)

$18 \mathrm{Id}$. at $576-81$. 
that we have full power and authority over the regulated carrier utilizing owner-operators; in fact, their relationship is now regulated in many respects. . . . Owner-operators are merely and simply the means or an instrumentality through which line-haul transportation is being performed in the name, under the responsibility, and pursuant to the operating rights of the carrier, and at its published rates. When acting for and on behalf of the authorized carrier the owner-operator has, thus, no independent status, in law or in fact, insofar as the shipping public is concerned. It seems obvious that the same should also hold true from a regulatory point of view. ${ }^{19}$

This argument, however, fails to take into account the language of the statute. The owner-operators are not carriers." The Commission's "full power" over carriers is no fuller than the statute provides. The section of the act ${ }^{21}$ which requires that carriers maintain records in accordance with Commission standards provides no more than that; the section does not require that carriers provide records other than their own. Under Freas' reasoning, it seems that the carrier could be compelled to show the costs incurred by any of its suppliers of services or materials. The only basis given for the dissent's assertion of power ${ }^{22}$ is the affirmation by the Supreme Court in American Trucking Ass'ns v. United States ${ }^{23}$ of the Commission's earlier promulgation of rules affecting the relationship between leasing carriers and their owner-operators. But the dissent's dependence hints of bootstraps, for the Court said:

What we have said above answers appellants' companion contention that the rules are invalid because they violate the National Transportation Policy as set out in 49 U.S.C. preceding $\S 1$. Regulation under the Act is there declared to be in the interests of the preservation of the inherent advantages of all modes of transportation, and of an economically sound, safe, and efficient industry. . . . But no overly-nice distinction between law and policy is needed to support the view that the question is hardly one for the courts; it is clear that the rules represent, at best, a compromise between stability and flexibility of industry conditions, each alleged to be in the national interest, and we can only look to see if the Commission has applied its familiarity with transportation problems to these conflicting considerations. ${ }^{24}$

19 Id. at 578 .

20 See Thomson v. United States, 321 U.S. 19 (1944); United States v. N. E. Rosenblum Truck Lines, Inc., 315 U.S. 50 (1941).

$21 \S 204$ (a) (1), 49 Stat. 546 (1935), 49 U.S.C. $\$ 304$ (a) (1) (1964).

22318 I.C.C. at 578.

23344 U.S. 298 (1953).

$24 I d$. at $313-14$. 
The rules promulgated by the Commission that received the Court's blessing did not, as the dissent suggests, extend the Commission's power to the owner-operators. They merely sought to formalize the relationship between leasing carriers and owner-operators so that the Commission could more accurately determine which owner-operators were working for which leasing carriers. No affirmative obligations were placed on the owner-operators; no affirmative obligations were placed upon the leasing carriers to require the performance of affirmative obligations of their owner-operators. ${ }^{25}$ The dissent's attempt to characterize the

25 The use of nonowned equipment by authorized carriers is not illegal, either under the Act or the rules under consideration. But evidence is overwhelming that a number of satellite practices directly affect the regulatory scheme of the Act, the public interest in necessary service and the economic stability of the industry, and it is on these that the rules focus. It appears, for instance, that while many arrangements are reduced to writing, oral leases are common; some were concluded after the trips were made and in several cases exempt operators solicited business themselves with blank authorized carrier forms or other evidence of agency. It is strongly urged that this very informality of the contractual relationship between carrier and exempt operator creates conditions in the industry inconsistent with those which the Act contemplates. Proof was proffered during the proceedings that the informal and tenuous relationships in lease and interchange permit evasions of the limitations on certificated or permitted authority. Since the driver of the exempt equipment is not an employee of the carrier, sanctions for violation of geographical restrictions are clearly difficult to impose, especially in the case of the singletrip lessor. Interchange may, as well, become a device to circumvent geographical restrictions in the certificate. The practice of authorized carriers conducting operations beyond the territory they are entitled to serve under cover of a lease from the local carrier was clearly shown in the evidence before the Commission. It appeared, in fact, that some of these operations are entirely fictional being created ad hoc after the trip is made-and this at times in the wake of a specific denial by the Commission of an application to serve the area.

It was also alleged, and shown by evidence of some incidents, that the Commission's safety requirements were not observed by exempt lessors. Because of the fact that the great bulk of the arrangements cover only one trip, leasing carriers have little opportunity or desire to inspect the equipment used, especially in cases where the agreement is made without the operator's appearance at the carrier's terminal. Enforcement sanctions by the carriers for violations would be clearly as difficult to impose as route standards. Hence, the carrier may not extend the supervision of rest periods, doctors' certificates, brakes, lights, tires, steering equipment and loading, normally accorded his own employees and vehicles, to equipment and drivers secured through lease. And the owner-operator himself is called upon to push himself and his truck because of the economic impact of time spent off the road and investment in repairs on his slim profit margin. (The conclusion that highway safety may be impaired rests admittedly on informed speculation rather than statistical certainty. A road check examination conducted by the Bureau did not indicate any significant difference in the number of safety violations between leased and owned vehicles.) [Footnote by the Court.]

The footnote undercuts the dissent's reference to safety. 318 I.C.C. at 579. The Court continued:

Further, the absence of written agreements has made the fixing of the lessee's responsibility for accidents highly difficult.

Consequences on the economic stability of the industry were also noted. The carrier engaged in leasing practice is at the mercy of the cost and supply of exempt equipment available to him. Hence, he may at times find himself unable to undertake shipping obligations because no trucks are available willing to make a relatively unprofitable trip or to assume the burdens of less-thancarload service.

American Trucking Ass'n v. United States, 344 U.S. 298, 303-05 (1953). (Emphasis added.) 
owner-operators as carriers thus must fail; ${ }^{26}$ they are not reached by the act. ${ }^{27}$

The dissent next contends that the majority erected a false barrier in deciding that since it could not compel the keeping of accounts, it could not acquire the information. "Insofar as I am able to determine, we have never rejected as valueless data presented by or for a carrier, a shipper, or anyone else, solely on the ground that they were not subject to the reporting or accounting requirements of the act." 28 This argument distorts the majority's position. The cost figures of the owner-operators were not rejected merely because there were no accounts and records kept by the owner-operators in the Commission-prescribed form against which they could be "verified"; they were rejected because without those records and accounts the costs could not be reliably developed by the Commission or the owner-operator. In other words, the figures were rejected because they were inherently unreliable. ${ }^{29}$

Hence, since the information cannot be developed without a uniform system of accounting, and since there is no Commission power to impose the system on the owner-operators, the Commission must either function in rate proceedings without the costs information or uniformly reject the attempts of leasing carriers to have a rate flexibility akin to that of selfsustaining carriers.

The dissent also contends that the rule proposed by the majority produces results inequitable to the self-sustaining carriers:

It would be quite inconsistent with the "fair and impartial regulation" demanded by the national transportation policy to accord carriers who use owner-operators special privileges or dispensation not afforded carriers using their own vehicles and

26 In United States v. Drum, 368 U.S. 370 (1962), the Court held that owneroperators carrying the goods of a shipper were contract carriers. The Court affirmed the Commission's reasoning that since the owner-operators furnished a special service to the shipper, maintained the equipment and bore the financial risk of the transportation, they were contract carriers within the statute. $\$ 203$ (a)(15), 49 Stat 544 (1935), as amended, 49 U.S.C. $\$ 303(a)(15)$ (1964). In the case of these owneroperators who work for carriers, however, there is no section of the statute which is applicable; furthermore in Drum the difference between deciding one way or the other was the difference between bringing the entire operation under regulation or leaving the whole operation outside regulation, except for matters of safety regulation. Here calling the owner-operators carriers would require the invention by the Commission of a category in which to put them. It seems obvious that if Congress had wanted the owner-operators to be carriers it would not have omitted or excluded them from the class of carriers by its definitions of carriers. In Drum there was a category; here there is not.

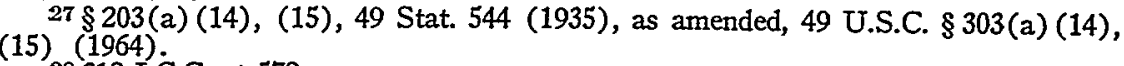
28318 I.C.C. at 578.

29 In Meats and Packinghouse Products from Midwest to Coast, 309 I.C.C. 551, $563(1960)$, the Commission accepted, in lieu of actual costs, evidence of the owneroperators' statistical estimates based on the tax returns of the owner-operators. The Commission characterized the results as "reasonably reliable" and "rough approximations." Apparently these approximations were the best evidence the Commission ever got of owner-operators' costs. The Iron or Steel Scrap majority concluded that "it is virtually impossible for carriers to collect and submit reliable cost data for representative owner-operator movements." 318 I.C.C. at 574. 
their own employees for the performance of their duties as public carriers. While the latter may be required to submit cost evidence concerning their service as a whole, yet the former would not be subject to the same but to a much lesser and perfunctory measure of proof. More importantly, the relaxed requirements for carriers using owner-operators would confer upon them an undue competitive ratemaking advantage. ${ }^{30}$

First, let us consider what the above quotation characterizes as the less important consideration - that the leasing carrier would have only a perfunctory burden to carry to achieve approval of its rates under the majority's rule. The leasing carrier would first have to prove that the proposed rate would produce revenue sufficient to yield a return compensatory to itself; it seems safe to assume that it could easily do so. Then it would have to prove that it could attract or retain the services of the owner-operators essential to its operation. Notwithstanding the dissent's protestations to the contrary, ${ }^{31}$ in practice this burden has not been so easily met. ${ }^{32}$ Furthermore it is a burden which need not be met by the self-sustaining carrier in the analogous situation; for example, the self-sustaining carrier is not required to show that the wages paid to its drivers are sufficient to acquire or retain their services. Finally, each kind of carrier is really doing the same thing; it is presenting to the Commission all the costs it has in its books. The self-sustaining carrier is not required to show to the Commission any records and accounts other than its own. If a self-sustaining carrier should purchase its trucks at half price so that its depreciation figures were halved, would the dissenting Commissioner require that the self-sustaining carrier produce the accounts of the seller of the trucks to prove their actual cost? Or would the carrier's cost be satisfactory?

Second, let us consider the competitive ratemaking advantage alluded to by Commissioner Freas. Obviously a ratemaking advantage is of no consequence unless it can be implemented; it cannot be implemented unless the conditions of the majority are met-i.e., that the services of the necessary owner-operators are available. But once the leasing carrier has achieved the approval and the implementation of the rate, the self-sustaining carrier is free to use the same rate since it can obtain the Commission's approval in a proceeding in which the only basis of decision is the rate comparison. Hence the case that must be considered is the case where the leasing carrier does implement the rate while the self-sustaining carrier cannot because its return on that rate would be less than its cost. Two obvious factors arise: There was no evidence in Iron or Steel Scrap that there were any competitors to whom the competition offered by the re-

$30 \mathrm{Id}$. at 578 .

31 Id. at 580 .

32 See, e.g., Sullivan Lines, General Commodities, East and Midwest, 325 I.C.C. 221 (1965); Tinplate from Fairless, Pa., to Hillside, N.J., 323 I.C.C. 642 (1964). 
spondent carrier would be destructive, ${ }^{33}$ and there was no hint in the majority opinion that the result would have been the same if there had been such evidence. Is it to be the task of the Commission to see that there is no competition in the transportation industry? It seems obvious that one of the Commission's functions is to balance competition with stability. Yet the position of the dissent is that the mere specter of competition which reduced rates to leasing carriers might evoke must be eliminated. We must suppose, of course, that the return to the owner-operators is less than compensatory-otherwise the discussion is merely one concerned with whether leasing carriers can use an inference that their ability to acquire or retain owner-operators' services implies that the owner-operators are being compensated. The discussion that this inference requires is of an entirely different nature since it entails no fundamental difference in the Commission's approach to ratemaking. ${ }^{34}$ Thus, supposing that there is no destructive competition and that the owner-operators are working for a less than compensatory return, we must turn to the implications of these assumptions.

The dissent suggests two different bases for the owner-operator's willingness to work for a less than compensatory return. The first draws a picture of the vagabond, indigent owner-operator stranded away from home, willing to drive for the leasing carrier for bare expenses. ${ }^{35}$ To the extent that this owner-operator's situation is worthy of serious concern, it seems obvious that he will be better off under the majority's rule than under the dissent's since, according to the dissent, the majority's rule will tend to increase the demand for owner-operators, thereby tending to eliminate the stranded, destitute owner-operator. It seems inconceivable that a leasing carrier will be able to convince the Commission under the second criterion of the Iron or Steel Scrap rule that enough vagabonds exist to supply the service in question. Furthermore the operation of the rules ${ }^{36}$ requiring a written contract and a period of exclusive carrier use of the vehicle for not less than thirty days, approved in American Trucking Ass'ns v. United States, ${ }^{37}$ appears designed to eliminate this kind of relationship.

The other suggestion of the dissent is that owner-operators will be willing to work for less than compensatory returns because they have favorable hauls in the other direction so that as far as they are concerned, an all expenses paid return trip is satisfactory. ${ }^{38}$ It is difficult to see why

33 The rate had been in effect for seven years, during which no competitors came forth to protest their being destroyed by it. 318 I.C.C. at 575 . Perhaps the dissent assumes that the competitors were destroyed before they could protest.

34 See text accompanying notes $54-62$ infra.

35318 I.C.C. at 579.

3649 C.F.R. $\$ 207.4(a)$ (1)-(4) (1964).

37344 U.S. 298 (1953).

38318 I.C.C. at 580 . It is also conceivable that a shipper may wish to ameliorate some of the expenses of its otherwise empty back hauls by leasing its trucks for the back hauls. The reasoning in Red Ball Motor Freight, Inc. v. Shannon, 377 U.S. 311 
the leasing carrier who is fortunate enough to encounter this situation should not be permitted to take advantage of it. The stability of this carrier is not in question since, in order to obtain approval of the rate, it has had to show that it can continue to obtain the necessary services under the second criterion of the rule. Hence nothing is in question except whether the carrier can take advantage of a bargain. If it could make an advantageous contract with its drivers and if it could make an advantageous purchase of its gasoline, there would be no objection. Why then can it not make an advantageous purchase of its raw transportation? Even if the same carrier were responsible for the movements in both directions, having made separate contracts for the front haul and the back haul with the same owner-operators, one of which was more lucrative than the other, so that it could allocate its costs in order to produce a "bargain" haul in one direction, it is not altogether clear that these arrangements ought to be impermissible. A self-sustaining carrier could do the same thing by allocating its lowest cost trucks to one movement in order to seek a reduced rate, for purposes of more effective competition on that movement. In the case where the carriers in the two directions are different carriers, it seems clear that the leasing carrier who has gotten the owner-operators for a less than compensatory return has managed to gain its advantage largely at the expense of the front haul carrier who is paying enough for the movement in the opposite direction to extinguish the owner-operators' interest in further profits. ${ }^{39}$ The operation of the market place, a factor considered by the dissent in only a single dimension-that of the increased demand for a service that has advantages-tempers the entire thrust of the argument. In the event that the proliferation of leasing arrangements forecast by the dissent actually comes about, it seems obvious that considerations of the owner-operators working for less than compensatory returns will become completely academic since it will become more and more difficult to engage them for less than compensatory returns. Indeed, the explanations offered now seem wholly inadequate. What we might expect to witness as their number increases is a reduction in the number of trucks owned by the formerly self-sustaining carriers to the minimum required by them for

(1964), militates against this possibility, since the Supreme Court there held that a shipper using its back haul capacity for transportation not related to its business must become a licensed carrier. An arrangement by the shipper to circumvent the holding in Red Ball by leasing its trucks would seem to be ill-destined. See Agricultural Transp. Ass'n v. United States, 349 F.2d 873 (5th Cir. 1965).

39 The front haul carrier's generosity itself suggests that its rate may be the one which is not just and reasonable. It is too high. Adopting the dissent's reasoning, it follows that the generous carrier has acted to the benefit of the leasing carrier and to the detriment of the competing self-sustaining carrier. Perhaps the self-sustaining carrier's energy should be directed to the generous carrier, instead of the leasing carrier. The energy would then be expended to reduce an overly-excessive rate rather than to increase a low, but viable, rate.

In the case of a shipper which is attempting to avoid the losses of empty back hauls, it seems questionable that it will continue to operate in an expanding market for an extended time for just expenses. Even if it does, the shipper's contribution to increased efficiency is neither different from nor less valuable than the owneroperator's. 
full-time service and the hiring by them of owner-operators to meet requirements during periods of high activity. Since the demand for the owner-operators will have increased, we might expect that the current leasing carriers will begin to depend more and more on trucks owned by themselves up to that same minimum (here, a maximum). Hence we might look forward to a different kind of stability, one where each carrier owns the equipment that it requires on a full-time basis and leases what it needs in excess-the owner-operator simply forming a pool of transportation which appears where needed. Obviously, to the extent that such a final arrangement might come to exist, the policies of economy and efficiency would have been optimally served.

It is clear that the real advantage that the leasing carrier has is not that it can find owner-operators ready to be exploited, but that it need assume only the expenses that its service requires; it does not have to be burdened with trucks that are stationary; when trucks are not in use, they are in someone else's service so that the leasing carrier can escape the expense of inefficient ownership. It is the avoidance of unrequited depreciation that gives the leasing carrier its advantage over the self-sustaining carrier. It seems at least arguable that allowing the leasing carrier to take advantage of the increased efficency that comes with the use of owner-operators is worth the burdens of competition. The alternative seems to be to protect the carriers - both railroads and self-sustaining carriers-that have heavy investment at the expense of the leasing carriers and their owner-operators. Obviously if the result were to destroy the railroads as a system, or the self-sustaining carriers as an entity, the value of the position taken by the majority would pale. But the collapse of the railroads is not so imminent and the entry of these carriers into leasing so desirable that we need cower before them, especially since a desirable and possible result of the majority's position can be foreseen-that is, maximum utilization of trucking capacity. No one can question that in the long run the shipping public and the consuming public will be better served by an efficient transportation industry. A reserve supply of trucks, appearing only as the demand for them increases and in quantities sufficient to meet the demand, seems desirable. The Commission's position in Iron or Steel Scrap seemed correctly contoured to allow the development of that possibility while simultaneously protecting the carrier from excessive zeal and instability.

\section{The Commission's Recantation}

In Drugs and Related Articles, Nere Jersey to Chicago, 40 the Commission approved a rate reduction pursuant to the rule of Iron or Steel Scrap. Eastern Central Motor Carriers Association, a protestant in Drugs and Related Articles, appealed the Commission's decision, attacking not the manner of the Commission's application of the rule in Drugs and Related Articles, but rather the promulgation of it in Iron or Steel Scrap. 
The district court reversed and remanded to the Commission for reconsideration. ${ }^{41}$ The Commission reconsidered and modified its rule, recanting its position that only the carrier must receive a compensatory return and returning to the position that the carrier must prove that the rate is compensatory to the costs of the movement, ${ }^{42}$ but allowing as part of this proof the inference that the compensation received by the owner-operators is compensatory if it is sufficient to acquire or retain their services. Once again the Commission allowed the rate reduction to the carrier. The reversing court then granted Eastern Central's motion to declare the Commission's reconsideration decision a nullity because it was inconsistent with the court's remand. ${ }^{43}$

In order to decide whether the court correctly granted the motion of Eastern Central, it is necessary to consider the differences between the two decisions by the Commission in Drugs and Related Articles (in effect, the difference between the Iron or Steel Scrap decision and the second Drugs and Related Articles decison) and to understand what the court's first opinion meant.

In Eastern Central Motor Carriers Ass'n v. United States, ${ }^{44}$ the court's first conclusion after its consideration of the Iron or Steel Scrap case was that "no rational basis is here disclosed that makes the collection or submission of costs for owner-operator movements an impossibility." 45 The Commission had attributed that impossibility to "the present state of the law and Commission regulations." 46 The court did not deal with the Commission's interpretation of the "present state of the law and Commission regulations"; it simply rejected the Commission's conclusion that obtaining the cost information would result in requiring the owneroperators, like carriers, to keep records and accounts for the Commission. ${ }^{47}$ Hence the court was able to assume, notwithstanding that it had found no basis for the Commission's position that the information was impossible of collection, that the information was difficult of collection:

41 Eastern Cent. Motor Carriers Ass'n v. United States, 239 F. Supp. 591 (D.D.C. 1965).

42 Drugs and Related Articles, N.J. to Chicago, 326 I.C.C. 6, 11 (1965).

43 Eastern Cent. Motor Carrier Ass'n v. United States, Civil No. 1234-64, D.D.C., Jan. 11, 1966.

44239 F. Supp. 591 (D.D.C. 1965).

$45 I d$. at 599 .

46 See text accompanying note 16 supra.

47 If the court had meant to put its rejection of the Commission's position on the ground that the Commission had misinterpreted the state of the law or its regulations, one might expect that the court would have alluded to the Commission's error. Further, the court would then have been able to inform the Commission of the proper manner in which to apply the law or regulation. The court's decision, instead, that the Commission had shown no rational basis for needing more power than it has to compel the production of the evidence, implies that the evidence is available under the Commission's view of its power. Hence the court must have been saying that the Commission could achieve the production of the evidence with some degree of difficulty. It is that notion of a continuum of difficulty, culminating in a degree called impossibility, which predicates the court's opinion. 
Assuming that the acquisition of owner-operator costs, while not impossible, is nevertheless difficult, the question then becomes whether the need for production of the evidence out-weighs the burden placed on the carrier and owner-operator. In our opinion, in order to meet the standards of the National Transportation Policy and the requirements of the applicable statutes, the need does out-weigh the burden. . . .

The second requirement [that the amount paid to the owneroperators is sufficient to retain the services of owner-operators] is based on the assumption that an owner-operator will hire himself out to the carrier only if his earnings from his operations exceed his costs or expenses. This is patently questionable. . . . Thus a carrier can attract as owner-operator willing to be employed when the owner-operator's income will not defray his expenses. Obviously, this makes the rate non-compensatory and, therefore, unjust and unreasonable-contrary to Sections 216(b) and $216(\mathrm{~d})$ of the Interstate Commerce Act. ${ }^{48}$

What were the implications of these statements with respect to the court's mandate to the Commission on remand? First it must be observed that the line of analysis quoted was predicated on the assumption that the evidence could, albeit with difficulty, be collected. Since the analysis was so predicated, it follows that the court must not have meant it to apply if the evidence was impossible of collection; otherwise, of course, the predication would have been unnecessary-the court would have said: "Notwithstanding that the evidence is impossible of collection, the need for its production outweighs the misfortune that must befall the carrier and owneroperators who fail to produce it. . . ." Hence, it seems, the court's assumption left open to the Commission on remand the option to supply a rational basis for its position that the evidence was impossible of collection. But the assumption left open more than that to the Commission: since there is not a distinct boundary between impossibility and difficulty, there must be some degrees of difficulty of collection that would carry the balance the other way. So, then, the Commission on remand would be free to build a rational basis for its finding of impossibility of collection or for a finding of a degree of difficulty higher than that the court had balanced. ${ }^{49}$

$48239 \mathrm{~F}$. Supp. at 599-600 (emphasis in original).

49 One may envision a result of this distribution of responsibilities seemingly created by the court whereby the Commission develops a record finding a certain degree of difficulty, decides on the basis of that finding to promulgate a rule, and so promulgates. The court then finds that the Commission's record does not sustain that degree of difficulty but only a lesser degree inadequate to sustain its rule. On remand the Commission builds a record which does sustain a finding of a greater degree of difficulty than it had previously. The court balances anew. The question then arises: who is doing the balancing? See text accompanying note 64 infra for the court's answer. 
The dispositive element of the court's reasoning, however, militates against this reading of the mandate. The court concluded that the Commission's rule in Iron or Steel Scrap was inconsistent with Sections 216(b) and $216(\mathrm{~d})$. This conclusion was grounded on the following syllogism: (1) the Iron or Steel Scrap rule does not necessarily imply that a rate is compensatory (with respect to the costs of the movement); (2) rates which are not compensatory (with respect to the costs of the movement) are not just and reasonable; (3) therefore rates approved under the Iron or Steel Scrap rule are unjust and unreasonable. Since the syllogism's validity does not depend on whether the information is possible of collection, it follows that the rule of Iron or Steel Scrap would be illegal whether or not the information was possible of collection. Hence there would be no need for the predication used by the court. Yet operate on that predication it did.

Having concluded that the Iron or Steel Scrap rule was illegal, the court continued:

Carriers with self-sustaining operations are vying with carriers employing owner-operators. . . Under the criterion of the Iron or Steel Scrap case, applicable here, the same standard is not applied to carriers using owner-operators. They have only to prove that part of the revenue, the part they retain, exceeds their costs. . . Unequal treatment is accorded . . . . This, in our opinion, is unjust discrimination against the self-sustaining carrier, as prohibited by the National Transportation Policy. ${ }^{50}$

The value of this addendum to the opinion is uncertain; since the Iron or Steel Scrap rule is illegal according to the court's analysis, what is the contribution of the continuation of the argument to the effect that that illegality is an "unjust discrimination" when its effects are applied to only one kind of carrier?

The opinion concludes:

All that this court holds is that, in absence of sufficient reasons, when the costs method is used to prove the compensativeness of reduced motor carrier rates, that full production of evidence is required for both the self-sustaining carrier and the carrier using owner-operators, in order to meet the requirements of the National Transportation Policy and Sections 216 (b), (d) and (g)..$^{51}$

The italicized portion suggests again that the Commission was free on remand to offer sufficient reasons for its decision to adopt the rule of Iron or Steel Scrap; these reasons could only be that the information was impossible of collection or more difficult of collection than the court had

50239 F. Supp. at 600-01.

51 Id. at 601 . 
assumed. The alternative to supplying these reasons would be that the Commission must modify or abandon the rule of Iron or Steel Scrap.

The Commission on reconsideration, perhaps motivated by the elusiveness of the court's mandate, attempted to amplify its previous conclusion that the evidence was impossible of collection and adopted a standard different from the Iron or Steel Scrap rule.

In Iron or Steel Scrap, the Commission had said almost nothing in support of its conclusion that the owner-operator cost information was impossible of collection..$^{52}$ On reconsideration it extensively discussed the difficulty (impossibility) of collection:

Cost evidence which is presented by a carrier to show compensativeness will actually support such a finding only if the evidence can be substantiated and is reliable. Regulated carriers must maintain records in a prescribed manner and submit annual reports containing specified data to the Commission. Thus when such carriers present cost evidence, its validity is easily ascertained. The same is not true of any data concerning owneroperators. Furthermore, we have no authority to require them to maintain records in any particular manner and submit reports to the Commission. Thus, many owner-operators keep few if any records at all because their methods of operation do not necessitate it. This is largely attributable to the fact that it is often a oneman operation, which in practice extends beyond the transportation of the goods for the carrier. True, the owner-operator drives the truck, but he is also concerned with protecting the investment he has made in his equipment; he maintains the vehicle in good repair and is likely to do much of the work related thereto except major overhauls; he purchases the gas, oil, tires, and anything else pertaining to his truck; he decides for whom he shall haul and negotiates the appropriate contract perhaps, as here, guided by union standards; and finally he keeps his own "books," usually amounting to little more than accumulated sales slips and his checkbook. To assume that the owner-operator could or would prepare a statement of income and expense in the detailed and classified manner needed for costing purposes is totally unrealistic. Furthermore, what expenses to report for services other than driving the vehicle, such as repairing the vehicle, that many owner-operators perform for themselves is difficult to ascertain. Yet meaningful cost data is not possible without complete information. An item of major importance to any owner-operator is depreciation of the vehicle. Some owner-operators . . . are able to extend its service life . . . minimizing this expense item. This is without consideration of another type owner-operator who owns more than one vehicle... [whose] expenses

52 See text accompanying note 16 supra. 
. . would more nearly typify those of a carrier operating its own equipment . . . . A carrier . . . may use one or both of the above extremes in purchased transportation . . . . [making] extremely complicated the use of any cost data that might be collected for arriving at any average cost of purchased transportation. . . . Our conclusion that there is no validly determinable average cost is based on experience. With no average cost data, no comparison is possible with the specific data that might be collected, which is itself not subject to any verification by the Commission as previously mentioned. . . . Even if the carrier or the Commission did question the costs, there would be no possible way to verify them. Thus, the collection and publication of the owner-operator data would serve no useful purpose. ${ }^{53}$

The Commission's position comes essentially to the information's impossibility of collection because what cost information would be obtained would be inherently unreliable. Thus the Commission seems to reject the continuum of difficulty implicit in the court's opinion and to argue simply that no reliable information exists.

But the Commission also modified its rule.54 In Iron or Steel Scrap, the Commission had said:

It is possible to determine, in accordance with accepted costfinding principles, whether the division of revenue retained by the carrier covers all of its costs. When such a division of revenue fully compensates the carrier for providing the transportation service in question, the rate which produces that revenue must be regarded as reasonably compensatory. ${ }^{55}$

The Eastern Central court rejected that statement without pause; it conceded that the rate would be compensatory to the carrier but, because the rate might not produce revenue sufficient to cover the total costs of the movement, the court found that the rate would not be compensatory. ${ }^{56}$ On reconsideration, the Commission adopted the court's definition:

We believe that such data is unnecessary in view of the showing that must be made to meet the second criterion; namely, that the payment to owner-operators is sufficient to acquire or retain their service. This criterion demands positive evidence that owner-operators are willing to perform the movement under consideration at the specified payment and thereby either continue or establish a long-term relationship with the carrier. The carrier

53326 I.C.C. at 9, 10.

54 There is no express indication by the Commission in its reconsideration decision that the different approach to the second criterion of the Iron or Steel Scrap rule was a conscious departure from the earlier approach. See Bicarbonate of Soda and Sal-Soda, Syracuse to Chicago, 321 I.C.C. 150 (1963), which seems to apply the Iron or Steel Scrap rule as if it were the later modification.

55 318 I.C.C. at 574-75. (Emphasis added.)

$66239 \mathrm{~F}$. Supp. at 600 . 
must present a meaningful record of employment relating to the proposed transportation. . . . Thus, on the basis of evidence which meets the second criterion of the Iron or Steel Scrap case, we can infer that the payment to the owner-operators does, in fact, exceed their costs of operation. ${ }^{57}$

Hence the Commission reevaluated the use it would make of the second criterion of the Iron or Steel Scrap rule. It retreated from a form which focuses attention only on the carrier's well being and stability under its proposed rate to one which only requires circumstantial evidence of the compensatory character of a rate with respect to the costs of the movement. Thus the Commission returned to the costs of the movement basis of determining compensativeness of rates. The Commission had previously conceded that the owner-operators might be working at a loss. Thus under the Iron or Steel Scrap rule the Commission could approve a rate which produced revenue adequate to compensate the carrier and acquire or retain the services of owner-operators, notwithstanding compelling evidence that their services were acquired or retained by some advantage to them other than the share of the revenue received in compensation for their services. ${ }^{58}$ Under the modified rule of the reconsideration, such compelling evidence would defeat the inference. Both the Iron or Steel Scrap dissent ${ }^{59}$ and the Eastern Central court ${ }^{60}$ dwelled on this "defect" in the original rule; on reconsideration the Commission seemed to have cured it.

The most extreme reading of the reviewing court's opinion in Eastern Central is that: (1) the Commission failed to supply a rational basis for its position that the costs evidence was impossible of collection, and (2) the rule of Iron or Steel Scrap which the Commission had applied in its first Drugs and Related Articles decision was illegal because it permitted rates which were non-compensatory with respect to the costs of the movement. Even under this reading, the Commission complied with the remand. It first attempted to supply the rational basis the court had found wanting for the conclusion that the evidence was impossible of collection and, second, modified the application of the rule of Iron or Steel Scrap to obviate the possibility that it would approve rates even though it was aware that the showing under the second criterion did not imply that the owner-operators were being duly compensated.

The court had provided that the rule of Iron or Steel Scrap could not stand "in the absence of sufficient reasons." The sufficient reasons must have included impossibility or an inordinately high degree of difficulty of collection if the form of the court's analysis is to be credited since the court must have realized that the Commission would so view the remand. It is possible, of course, that the court misunderstood the import of the Commission's decision in Iron or Steel Scrap so that, on review of Drugs

57326 I.C.C. at 11. (Emphasis added.)

58 See text accompanying note 35 sipra.

59318 I.C.C. at 578-80.

60239 F. Supp. at 600 . 
and Related Articles, it conceived the Commission's position to be not what it was then, but what it was to be after the reconsideration. If the court did so misconceive the Commission's position, the court's response to the motion to enforce the judgment brought to declare the reconsideration decision a nullity is easily understood. Yet the court ought to have been able to comprehend that the reconsideration decision had eliminated the record's terseness on the question of the impossibility of collecting the evidence-surely the reconsideration record was sufficient in that regard to force the court to reconsider the question of what the Commission must do if the evidence was impossible of collection. The court's appeal decision was silent in that regard. The granting of the motion to enforce the judgment was equally silent. It seems clear that the Commission was entitled to have the motion denied, so that Eastern Central would have to appeal the Commission's reconsideration decision to reach a decision on the merits, which merits were not the same as those dealt with in the review of Drugs and Related Articles because the crucial issue on the reconsideration's review would necessarily have been the reliability of the inference of the second criterion of the Iron or Steel Scrap rule. In the review of Drugs and Related Articles, the reliability of the inference was not in issue because the Commission's formulation did not put it in issue; the second criterion served merely to assure the Commission of the carrier's stability. On the reconsideration of Drugs and Related Articles, the reliability of the inference was the key issue because, to the extent that it was reliable, there could be no objection to it. The court's characterization of the Commission's reconsideration decision as a mere reiteration totally fails to take into account that the Commission had, in that reconsideration, withdrawn its attempt to abandon the cost of movement basis in rate determinations. The court's statement in its opinion on the motion that the Commission "has overlooked the full purport of its Opinion" ${ }^{11}$ seems to suggest that in its first opinion the court decided a case that was not before it. The motion to enforce the judgment should have been denied. ${ }^{62}$

\section{The Reversal of Drugs and Related Articles}

Having explored the judgment of the Commission in Iron or Steel Scrap and the fate of the Commission's withdrawal from its Iron or Steel Scrap position in the reconsideration of Drugs and Related Articles, it

61 Drugs and Related Articles, Civil No. 1234-64, D.D.C., Jan. 11, 1966, at 2.

02 Whether the Commission will appeal the decision on the motion is at this time unclear. If it does appeal, the issue on the appeal will be whether the two Commission decisions, Iron or Steel Scrap and the reconsideration of Drugs and Related Articles, are different formulations. If the Commission loses this appeal, it would be foreclosed from applying either rule to the Drugs and Related Articles litigation, because the Commission's defeat would imply that the later formulation was the same as the earlier one, on which time to appeal had run out. It seems safe to predict that the Commission, committed to the principle of Iron or Steel Scrap as reformulated, would apply it in another litigation, thereby obliging the protestants to enter that litigation for a decision on the merits. If, in the other hand, the Commission won the appeal, the protestants would be able to engage the Commission in that battle on the merits in an appeal from the reconsideration decision. 
remains only to consider the court's reasoning in deciding that the Commission's judgment was wrong as a matter of law.

The court first rejected the Commission's conclusion that the costs evidence of the owner-operators was impossible of collection. Since the court said nothing about what led it to reject the Commission finding except that there was no rational basis for it, one must conclude that the court meant merely that the record compiled by the Commission was insufficient to explain the conclusion. In any case, immediately after having rejected the Commission's operative determination, the court entered upon a discussion of the balance between the need for the costs evidence and the "burden" of its production. ${ }^{33}$ Having decided to balance, logic would require that the court have some notion of what it was balancing. Since the record was insufficient to support a finding that the evidence could not be produced, the court's assumption of the "burden" of its production would have been dispositive of the result no matter what kind of analysis followed. Obviously the answer to the question depends specifically on the assumed degree of burden. Hence one is compelled to wonder whether anything that follows that assumption is worthy of comment.

What does follow that assumption is a still more curious display of circumlocution. Having involved the result of the balancing with the assumption so intimately that the result was inherent in the assumption, the court proceeded to develop an argument that was logically independent of the assumption so that the significance of the first defect in the court's reasoning pales before that of the second. The court decided that the Iron or Steel Scrap rule was illegal in an analysis unrelated to the possibility of difficulty of collecting the costs evidence. ${ }^{64}$ The court's finding was that the need for the production of the costs evidence was required by sections $216(\mathrm{~b}),{ }^{65}$ (d) ${ }^{66}$ and $(\mathrm{g}){ }^{67}$ of the act and the National Transportation Policy. ${ }^{68}$ We will examine that finding more closely: "Thus a carrier can

63239 F. Supp. at 599.

64 The court puts its thumb on one side of the scale and an infinite weight on the other.

6549 Stat. 558 (1935), 49 U.S.C. \$316(b) (1964). This section provides that all motor carriers shall "establish, observe, and enforce just and reasonable rates ... and just and reasonable practices relating thereto . . . and all other matters relating to or connected with the transportation of property in interstate or foreign commerce."

6649 Stat. 558 (1935), as amended, 49 U.S.C. \$ 316(d) (1964). This section requires all charges to be "just and reasonable" and prohibits "unjust and unreasonable" charges. This section also carries a provisio: "Provided, hozever, That this subsection shall not be construed to apply to discriminations, prejudice, or disadvantage to the traffic of any other carrier of whatever description." The proviso clarifies what would otherwise be clear: that the thrust of this section is to unreasonable charges made to shippers through discrimination, prejudice, or whatever. Its inapplicability to questions concerning rates of competing carriers seems obvious. The court seems to have been unaware of the proviso.

6749 Stat. 558 (1935), as amended, 49 U.S.C. $\$ 316(\mathrm{~g})$ (1964). This section provides that the burden of proving that a proposed rate change is just and reasonable is on the carrier which proposes it.

68 Interstate Commerce Act preceding \$201, 54 Stat. 899 (1940), 49 U.S.C. preceding $\S 301$ (1964). 
attract an owner-operator willing to be employed when the owner-operator's income will not defray his expenses. Obviously, this makes a rate non-compensatory . . . " 89 It is obvious that an owner-operator who works for less than compensatory returns may make a rate non-compensatory with respect to the costs of the movement; it is neither obvious nor true that his so doing makes the rate non-compensatory with respect to the expenses of the carrier. The Commission had adopted the latter meaning in Iron or Steel Scrap. ${ }^{70}$ The court merely ignored the crucial issue in the case. Having reached the conclusion that the rate would be non-compensatory by assuming that the rate must be compensatory with respect to the costs of the movement, the court's first step was complete. "Obviously, this makes a rate non-compensatory and, therefore, unjust and unreasonable-contrary to Sections 216(b) and 216(d) of the Interstate Commerce Act." 71 Nothing in either section cited by the court compels the result. Malone Freight Lines, Inc. v. United States, ${ }^{72}$ cited by the court for its affirmance of the Commission's pre-Iron or Steel Scrap position requiring production of the owner-operator's costs, similarly made the deduction that rates must be compensatory to be just and reasonable:

Whether rates are just and reasonable within the nebulous statutory standard is a question of fact to be resolved by the Commission after according appropriate weight to evidence offered in their support. . . . It seems obvious that rates which are not compensatory are not just and reasonable. Chicago \& E. Ill. R.R. v. United States, 107 F. Supp. 118 (S.D. Ind. 1952), aff'd mem., 344 U.S. 917 (1953)..$^{73}$

The case relied on by this court, in turn, for the implication was one in which the rate was not shown to be compensatory to the carrier. It therefore emerges that, in the two cases which raised the issue whether the rate must be compensatory to the costs of the movement or compensatory only to the expenses of the carrier, the issue has not been faced. Clearly, unless the issue is faced, the reliance on sections $216(\mathrm{~b})$ and (d) is uncertain at best. 74

Notwithstanding its conclusion that the standard of Iron or Steel Scrap was illegal, the court proceeded to an argument that the requirement of total costs evidence from self-sustaining carriers and only partial evidence from leasing carriers was an "unjust discrimination" within the meaning

$69239 \mathrm{~F}$. Supp. at 600 (emphasis in original).

70 See text accompanying note 17 supra.

71239 F. Supp. at 600.

72204 F. Supp. 745 (N.D. Ala. 1962).

73 Id. at 754-55.

74 The holding in Baltimore \& O.R.R. v. United States, 345 U.S. 146 (1953), makes the result even more uncertain. The Supreme Court there held that a railroad carrier must suffer a non-compensatory rate if its overall operation was compensated under comprehensive schedules. Hence judicial approval of non-compensatory rates is not entirely unknown. 
of the National Transportation Policy. At the outset of its opinion, the court quoted the National Transportation Policy in full:

It is hereby declared to be the national transportation policy of the Congress to provide for fair and impartial regulation of all modes of transportation subject to the provisions of this Act, so administered as to recognize and preserve the inherent advantages of each; to promote safe, adequate, economical, and efficient service and foster sound economic conditions in transportation and among the several carriers; to encourage the establishment and maintenance of reasonable charges for transportation services, without unjust discriminations, undue preferences or advantages, or unfair or destructive competitive practices; to cooperate with the several States . . . to encourage fair wages . . . ${ }^{75}$

The italicized portion of the above modifies "charges" which are to be established by the carriers. The court's patently erroneous reading treats that portion as if it modified "to encourage." The reading requires that there be meaning in the notion of the Commission's encouraging without unfair or destructive competitive practices. That the court meant to read the statement in this manner is demonstrable:

Unequal treatment is accorded on the one hand to the carriers who own and operate the equipment and who are required to submit refined and detailed costs data to assure compensativeness and, on the other hand, to the carriers who lease the equipment and crew and who submit a lump sum covering the cost of rental equipment and crew and add to that only administrative and overhead costs and profit. This, in our opinion, is unjust discrimination against the self-sustaining carrier, as prohibited by the $\mathrm{Na}$ tional Transportation Policy. ${ }^{76}$

The issue before the court was whether the circumstances surrounding the collection of owner-operator cost data justified the Commission in defining the costs to which rates must be compensatory as those of the carrier, with the proviso that the carrier must show that it could acquire or retain owner-operators to perform its service. The court did not analyze the circumstances; it did not deal with the dispositive issue of whether the Commission was free to define compensatory with respect to the costs of the carrier. Instead, the court invented two statutory issues ${ }^{77}$ to give

75239 F. Supp. at 595 (emphasis in original).

76 Id. at 601. (Emphasis added.) Apparently, it did not occur to the Commission to read the National Transportation Policy. On remand the Commission acquiesced in the court's reading. The Commission decided merely that its discrimination was reasonable-not "unjust." 326 I.C.C. at 11-12.

77 A statutory issue that might have appropriately been raised was not raised. Section 208(a) of the act provides that the carrier shall not be limited in its right 
substance to its position since that position was no more than an agreement with the result reached by one group of Commissioners as opposed to the result reached by another group about the more politic solution to the problem presented and the need to find a solution.

Conceivably the Commission had failed to fulfill its obligation to explain to the court why the costs of the owner-operators were impossible of meaningful assemblage; for that reason the court might have remanded. ${ }^{78}$ The court's handling of the motion to enforce the judgment, however, suggests that this failure was not even a reason for the remand.

It is possible, of course, to speculate about the court's motives in rejecting the Commission's adoption of the Iron or Steel Scrap rule; its application would involve the Commission in a judgment more subtle than arithmetical costs judgments, a judgment devoid of the clean edges of numerical reality. But mathematical precision does not create truth; it can only preserve it.

\section{CONCLUSION}

The discussion began with the Commission's attempt in Iron or Steel Scrap to free the leasing carriers from a restriction it had placed upon them. The attempt to collect owner-operator costs, the Commission decided, was fruitless. Hence the Commission decided that, so long as the carrier was compensated and stabilized, the proposed rate would be approved. On appeal the court ignored the substance of what the Commission had attempted to do and concentrated on the possibility that the competitive position of some self-sustaining carrier might be prejudiced or at least injured. The court did not consider that its decision might well deprive the leasing carrier of any effective rate flexibility. Since it is clear that in only some cases would the Iron or Steel Scrap rule produce rates incapable of producing returns compensatory to the cost of movement and thereby work against the interests of the self-sustaining carriers, and equally clear that the opposite rule would work against the interests of the leasing carriers in all cases, it seems that the court ought to have balanced these interests. On the other hand, to the extent that efficiency is an

to augment its equipment. $\$ 208$ (a), 49 Stat. 552 (1935), 49 U.S.C. $\$ 308$ (a) (1964). Since the effect of requiring a carrier to do the impossible or the very difficult in order to lease from owner-operators is essentially to stop it from using their services if it wants rate flexibility (or, if it depends on them entirely, to destroy it), the question arises whether the carrier's being forced to discontinue its relationship with its owner-operators is an interference with its right to augment its equipment. This consideration was not mentioned in this litigation. Mr. Justice Black, however, raised it in his dissent in American Trucking Ass'ns v. United States, 344 U.S. 298, 327 (1953). This case was the culmination of a series of Commission investigations, reported as the Lease and Interchange of Vehicles by Motor Carriers, 51 M.C.C. 461 (1950), 52 M.C.C. 675 (1951), which produced two more cases, 64 M.C.C. 361 (1955), 68 M.C.C. 553 (1956). These reports should be consulted for an agonizing excursion through the formulation of the rules finally approved by the Court, but not finally promulgated entirely by the Commission. See Agricultural Transp. Ass'n v. United States, 349 F.2d 873, 881-83 (5th Cir. 1965).

${ }^{78}$ Cf. ICC v. J-T Transport Co., 368 U.S. 81, 126-30 (1961) (Frankfurter, J., dissenting). 
important element in the long range outlook of the Commission, the court should have made some attempt to analyze the long range results of the Iron or Steel Scrap rule. At the very least the Commission's attempt to ameliorate the problem should have been studied by the court sufficiently to enable it to tell the difference between the Commission's decision in Iron or Steel Scrap and the Commission's decision on reconsideration of Drugs and Related Articles. Under the reformulation in which the Commission returned to the costs of the movement basis, the leasing carrier's difficulties would be largely resolved, since only in those few cases where the rate was not justified by the inference would the leasing carrier fail to gain approval of its proposed rate. Ultimately the question which must be resolved is whether the protection of the large self-sustaining carriers is worth the price in efficiency that must be paid. One of the manners in which insight into this question can be gained is to allow the Commission sufficient freedom to experiment. The proliferation of owner-operators and increased dependence on their services may conceivably unstabilize the industry. But it will not unstabilize the industry so quickly that the Commission cannot prevent serious disruption. Hence, in that area where there is room for experiment, it seems that the courts should tread carefully before interfering with the Commission's attempt to solve the problems it senses in transportation. In this litigation, no single direct competitor ever came forward to claim injury; the railroads joined the rate bureaus in a cry of fear for the future. Surely it should be obvious that the concern for the future health of the industry has not been entrusted to the courts, but to the Interstate Commerce Commission. ${ }^{79}$

The Commission has twice in this litigation plunged into the murky waters of judicial review and twice sunk. Before sinking for the third time the Commission should have the opportunity to determine the validity of the propositions that a leasing carrier should be able to purchase its raw materials at the best price it can without incurring a penalty, and that a man in general works for profit.

The public and the Commission are entitled to more than unreasoned syllogisms and meaningless classifications. During a period in which the results of the release of owner-operators into the market are uncertain, the public is entitled to the benefit of the doubt in the form of lower cost transportation. The Commission's forced retreat before the specter of future chaos is unacceptable.

79 "If . . the court meant to substitute its judgment for the Commission's on the question... we think ... it indulged in an unwarranted incursion into the administrative domain. Reversed." United States v. Drum, 368 U.S. 370, 386 (1962). 